\title{
A Decrease in Carbon Absorption Potential Due to Timber Harvesting in Natural Forest
}

\author{
Yuniawati ${ }^{*}$, Rossi Margareth Tampubolon \\ Forest Products Technology Research and Development Center, Research, Development and Innovation Agency, The Ministry of \\ Environment and Forestry. Gunung Batu Street No. 5, Bogor, 16610, West Java, Indonesia \\ * Corresponding author.E-mail address: yunia_las@yahoo.co.id
}

\section{ARTICLE HISTORY:}

Received: 14 February 202

Peer review completed: 17 March 2021 Received in revised form: 25 March 202 Accepted: 9 April 2021

\section{KEYWORDS}

\section{Biomass}

Carbon emission

Timber harvesting
(C) 2021 The Author(s). Published by Department of Forestry, Faculty of Agriculture, University of Lampung in collaboration with Indonesia Network for Agroforestry Education (INAFE) This is an open access article under the CC BY-NC license:

https://creativecommons.org/licenses/by$\mathrm{nc} / 4.0 \%$.

\begin{abstract}
Timber harvesting is an activity in producing wood to supply the lumber industry. However, timber harvesting brought consequences such as decreasing the carbon sequestration potential of natural forests. This study aimed to determine the reduction in the potential for carbon sequestration due to timber harvesting in natural forests. Data were collected using nondestructive methods through stand inventory before felling for all tree species, cruising results report, and tree distribution maps. Biomass was calculated using the existing allometric, and carbon stocks were calculated using the Intergovernmental Panel on Climate Change method. The results showed that there were 238 trees $\left(65.29 \mathrm{~m}^{3}\right)$ of stands in the study area $(6$ ha) based on stand inventory before felling. The potential biomass and carbon storage before trees felling were 16.12 ton ha ${ }^{-1}$ and 7.58 ton ha ${ }^{-1}$, respectively. The results also revealed that the potential biomass and carbon storage after tree felling were 5.15 ton $\mathrm{ha}^{-1}$ and 2.42 ton $\mathrm{ha}^{-1}$, respectively. Carbon absorption before and after tree felling is 28.37 ton $\mathrm{CO}_{2 \mathrm{eq}} \mathrm{ha}^{-1}$ and 4.44 ton $\mathrm{CO}_{2 \mathrm{eq}} \mathrm{ha}^{-1}$, respectively. Carbon emissions during tree felling was 18.93 ton $\mathrm{CO}_{2 \mathrm{eq}} \mathrm{ha}^{-1}(81.00 \%)$. The application of environmentally friendly wood harvesting shall be carried out appropriately to minimize a decrease in carbon absorption from timber harvesting.
\end{abstract}

\section{Introduction}

Forests could absorb carbon in vegetation and soil and absorb $\mathrm{CO}_{2}$ from the atmosphere through photosynthesis. However, forests also could become sources of $\mathrm{CO}_{2}$ emissions in the atmosphere when forests are disturbed. Forest type classification is an important determinant of the above-ground biomass estimation when altitudinal and other complex environmental gradients are included (Alvarez et al. 2012). Timber harvesting has an important role in timber production, and one of the activities is tree felling. Tree felling could result in a decrease in carbon absorption. Sist et al. (2003) stated that the high intensity of logging in natural forests that exceeds 10 trees/ha could decrease carbon stocks in Indonesia's tropical natural forests. Garcia et al. (2019) reported that in the 12,924 ha of forest dominated by Pinus hartwegii in plantation forest, $1,695,004 \mathrm{MgC}$ was contained in above-ground biomass. Garcia et al. (2019) obtained data on forest harvesting by analysis of recent cut stumps and estimated the removal of 42,701 $\mathrm{MgC}$. In addition, Garcia et al. (2019) accounted for carbon in the wind-thrown trees of $14,904 \mathrm{MgC}$, some of which were 
removed over time in harvests. Total loss of carbon from the forest corresponded to 211,218 $\mathrm{MgCO}_{2}$ per year.

Ximenes et al. (2016) stated that loss of total biomass due to timber harvesting is not considered as direct carbon loss but is seen as a transfer of carbon stock from forest to wood products. The research result of Pukkala (2018) showed that when the long-term carbon balance of forestry is maximized, the harvesting level should be low. Poudyal et al. (2019) stated that the timely harvesting of mature trees and minimal damage to neighboring plants might help to stock more carbon in harvested forest products as well as in the forest biomass.

Timber harvesting for wood products has the potential to store more carbon than conserved forests over the long term given the higher standing tree volume and long-term use of wood products (Russel and Kumar 2017), with cascading wood use extending the time of storage, which further delays contribution to the greenhouse effect (Höglmeier et al. 2015). Heinonen et al. (2017) stated that timber harvesting reduces the carbon stocks of forests compared to unharvested forests. Cardenas et al. (2018) stated that the mechanism by which harvesting can exacerbate nitrogen losses at sites predisposed to such losses, potentially lowering plant productivity and increasing greenhouse gas emissions. Based on this background, the purpose of this study was to determine a decrease in the potential for carbon sequestration due to timber harvesting in natural forests.

\section{Materials and Methods}

\subsection{Research Location}

The research was conducted in the working area of Commercial Timber Forest Products Utilization Permit of Natural Forest (HPH) PT. Inhutani I Unit Sambarata, Berau Regency, East Kalimantan, Indonesia. The study was conducted from November-January 2016.
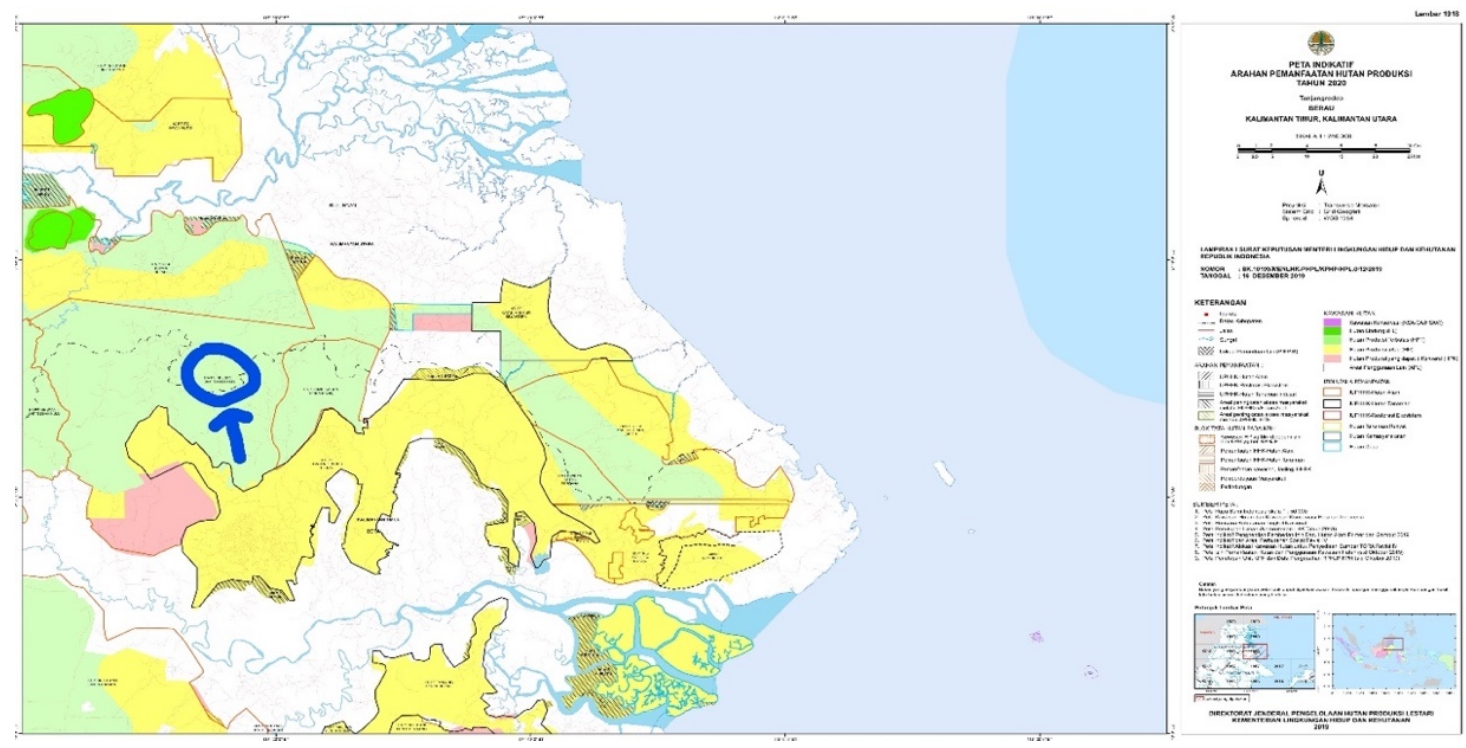

Fig. 1. The location of study.

\subsection{Materials and Equipment}

Materials used were trees, stand inventory before logging for all tree species, cruising results report, tree distribution maps, chalks, and paint. Equipment used were phi-band and measuring tape for measuring diameter and length of logged trees, tally sheet, clinometer for measuring slope, compass, digital camera for documentation, stationery, and machete. 


\subsection{Data Collection}

This study used primary and secondary data. Primary data was obtained by direct observation in the field. The primary data collected were tree dimensions as diameter at breast height $(\mathrm{DBH})$ and tree height. Secondary data were obtained by reviewing documents available in the research location, such as the general condition of the natural forest concession area (forest condition, position and area size, topography, climate, stand inventory before logging for all tree species, and cruising results report).

\subsection{Working Procedures}

In the selected logging compartments in the natural forest concession area, as many as 3 Observation Sample Plots (OSP) measuring 2.0 ha $(200 \mathrm{~m}$ x $100 \mathrm{~m})$ each, were constructed. Positions of the OSP were designed by systematic sampling with a purposive start (Kusmana 2017), where the first OSP was determined purposively in the selected logging compartment, and the next OSP was positioned systematically with a distance between OSPs of $100 \mathrm{~m}$. The method used is non-destructive by direct measurement of DBH and tree height on 3 OSP. All tree species stand data on logging compartments number 339 were obtained from stand inventory before logging for all tree species, cruising results report, and tree distribution maps. To estimate the decrease in tree carbon stock and carbon sequestration obtained from the difference between the decreasing of carbon stock before logging and after logging. The estimation of the absorption of $\mathrm{CO}_{2}$ released into the atmosphere is the result of multiplying the amount of carbon lost with the conversion factor from carbon (C) to carbon dioxide $\left(\mathrm{CO}_{2}\right)$ of 3.67 (IPCC 2006).

\subsection{Data Analysis}

\subsubsection{Biomass calculation}

Above-ground biomass (AGB) was calculated using allometric equations (Chave et al. 2005) as follows:

$$
A G B(\mathrm{~kg})=0.0509 \times \rho \times D^{2} \times H
$$

where $\rho$ is the specific gravity of wood $\left(\mathrm{g} / \mathrm{cm}^{3}\right), D$ is the diameter at breast height $(\mathrm{cm})$, and $H$ is total tree height $(\mathrm{m})$. The density of the wood used refers to a literature study according to Hairiah et al. (2011), namely $0.61 \mathrm{~g} / \mathrm{cm}^{3}$ in a logged-over forest.

\subsubsection{Calculation of carbon stock}

Carbon stock was calculated using IPCC (2006) equation as follows:

Carbon Stock $\left(\right.$ ton $\left.\mathrm{ha}^{-1}\right)=B \times 0.47$

where $B$ is total biomass (ton ha-1), and 0.47 is the carbon content.

\subsubsection{Calculation of $\mathrm{CO}_{2}$ equivalent}

$\mathrm{CO}_{2}$ equivalent was calculated using the following equation:

$$
\mathrm{CO}_{2 e q}=\frac{44}{12} \times \text { Carbon Stock }
$$

where $\mathrm{CO}_{2 e q}$ is used to standardize the climate effects of various greenhouse gases (tonCO $\mathrm{O}_{2} \mathrm{eq}$ ), $44 / 12$ is the ratio of molecular weight of $\mathrm{CO}_{2}$ to carbon. 


\section{Results and Discussion}

\subsection{Conditions of the Forest Stand Before and After Logging}

In the study area, logging compartments number 339, the area of 3 OSP was 6 ha, with a distribution of 238 trees. The felling of 3 OSP was 30 trees. Tree species and composition at 3 OSPs before felling are presented in Fig. 2. Meranti (126 trees) and Keruing (56 trees) dominated the tree species in the study area (Fig. 2). Meranti has a diameter at breast height (DBH) of 30-80 $\mathrm{cm}$ with tree heights of 13-24 m, while Keruing has a DBH range of 40-60 cm and a tree height of 14-21 $\mathrm{m}$ (Table 1). The variation in the range of DBH and tree height in the study area has a high potential for carbon sequestration. Trees that dominate an area have the ability to grow large so that the size of the DBH becomes large, and in the end, it will be able to store more carbon. The stem diameter will be directly proportional to the biomass value. The greater the DBH indicated that old trees store more carbon than young trees (Istomo and Farida 2017). Kasianus et al. (2018) stated that the amount of potential carbon converted from biomass is strongly influenced by tree diameter.

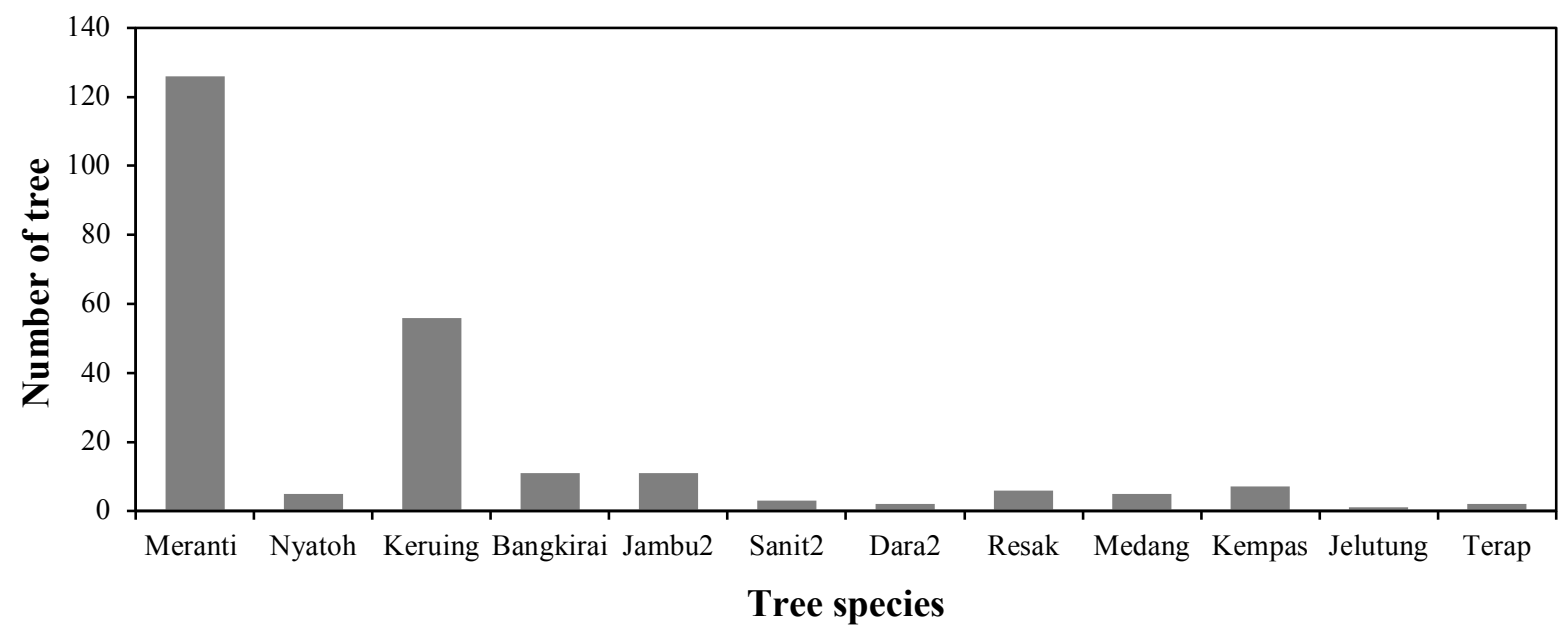

Fig. 2. Tree species and composition in the study area.

Table 1. Condition of tree diameter and height in the study area

\begin{tabular}{lccc}
\hline \multicolumn{1}{c}{ Scientific name } & $\begin{array}{c}\text { Local name/ } \\
\text { commercial name }\end{array}$ & $\begin{array}{c}\text { Diameter } \\
\text { (cm) }\end{array}$ & $\begin{array}{c}\text { Height } \\
\text { (m) }\end{array}$ \\
\hline Shorea & Meranti & $30-80$ & $13-24$ \\
Palaquim sp & Nyatoh & $45-60$ & $15-19$ \\
Dipterocarpus & Keruing & $40-60$ & $14-21$ \\
Shorea laevis Ridl & Bangkirai & $45-80$ & $15-22$ \\
Syzygium & Jambu-jambu & $35-70$ & $14-17$ \\
Sanit-sanit & Sanit-sanit & 40 & $14-14$ \\
Dara-dara & Dara-dara & 40 & 14 \\
Vatica & Resak & $40-51$ & $14-16$ \\
Phoebe & Medang & $40-63$ & $14-17$ \\
Koompassia excelsa & Kempas & $40-56$ & $14-16$ \\
Dyera costulata & Jelutung & 60 & 19 \\
Artocarpus odoratissimus & Terap & 40 & $14-15$ \\
\hline
\end{tabular}

The tree species and number before and after felling are presented in Fig. 3 and Table 2. The results showed a reduction in tree species and number after felling by 208 trees $(12.61 \%)$ (Fig. 3 and Table 2). This reduction results in a reduction in the potential for carbon sequestration at the 
study site. Superales (2016) stated that plant stems act as carbon storage produced from the absorption of air carbon dioxide with the ability to store $34 \%$ greater than leaves. As the main constituent of forests, trees require sunlight, carbon dioxide $\left(\mathrm{CO}_{2}\right)$ absorbed from the air, and nutrients and water absorbed from the soil (Lukito and Rohmatiah 2013).

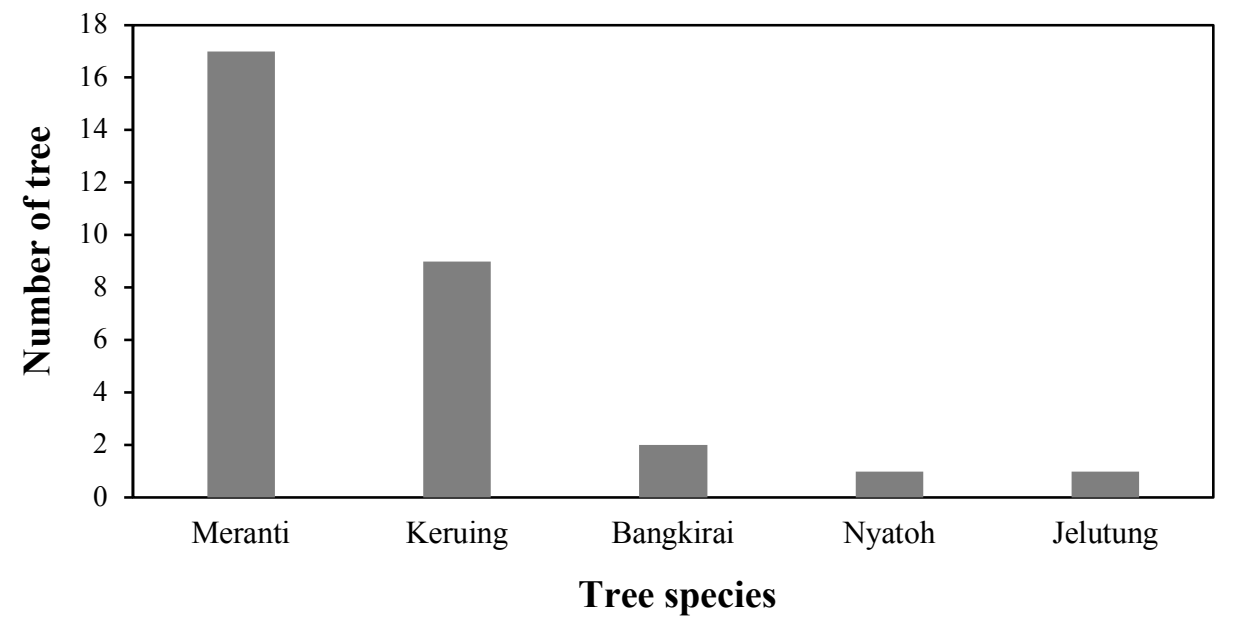

Fig. 3. The species of the felled tree.

Table 2. Number of trees before and after felling

\begin{tabular}{lc}
\hline Timber stand condition & Number of tree (tree) \\
\hline Before felling & 238 \\
During felling & 30 \\
After felling & 208 \\
\hline
\end{tabular}

The average volume of logs felled at $4.92 \mathrm{~m}^{3}$ whereas before felling was $3.26 \mathrm{~m}^{3}$. This is because the diameter of the trees to be felled average is $60 \mathrm{~cm}$ with 30 trees in 3 OSP (Table 3 and Table 4). The large diameter of the trees to be felled causes the volume of stands to be larger, whereas in the pre-felled condition, there is a mixture of tree diameter sizes ranging from 0.3-1 $\mathrm{m}^{3}$. Stand volume indicates the potential for timber production in a certain area. The number of trees before felling will be reduced due to logging production activities.

Table 3. The average standing volume before felling

\begin{tabular}{lccc}
\hline OSP & Height $(\mathbf{m})$ & Diameter $(\mathbf{m})$ & Volume $\left(\mathbf{m}^{\mathbf{3}} /\right.$ tree $)$ \\
\hline I & 14.75 & 0.46 & 2.54 \\
II & 14.93 & 0.52 & 3.27 \\
III & 16.46 & 0.53 & 3.98 \\
Average & 15.38 & 0.50 & 3.26 \\
\hline
\end{tabular}

Table 4. The average volume stands of felled

\begin{tabular}{lccc}
\hline PCP & Height $(\mathbf{m})$ & Diameter $(\mathbf{m})$ & Volume $\left(\mathbf{m}^{3} /\right.$ tree $)$ \\
\hline I & 19.50 & 0.60 & 4.45 \\
II & 20.00 & 0.60 & 5.72 \\
III & 20.00 & 0.60 & 4.60 \\
Average & 19.83 & 0.60 & 4.92 \\
\hline
\end{tabular}




\subsection{Biomass and Carbon Before Felling}

The tree stand biomass affects the potential for carbon storage. Maryadi et al. (2019) stated that the increase in the amount of carbon is directly proportional to the increase in biomass. The higher the amount of biomass, the higher the amount of carbon stored. The results of measurements of the potential biomass and forest stand before logging are presented in Table 5.

Table 5. Potential biomass before felling

\begin{tabular}{lccccc}
\hline Biomass (kg) & $\begin{array}{c}\text { Biomass } \\
\left(\mathbf{k g ~ h a}^{-\mathbf{1}}\right)\end{array}$ & $\begin{array}{c}\text { Biomass } \\
\left(\mathbf{t o n ~ h a ~}^{-\mathbf{1}}\right)\end{array}$ & $\begin{array}{c}\mathbf{C} \text { stock } \\
\left(\mathbf{t o n ~ h a}^{-\mathbf{1}}\right)\end{array}$ & $\begin{array}{c}\mathbf{C O}_{2} \text { equivalent } \\
(\text { tonCO } \mathbf{e q})\end{array}$ \\
\hline Total & $96,702.42$ & $16,117.07$ & 16.12 & 7.58 & 28.37 \\
Average & 406.31 & 16.12 & 0.07 & 0.03 & 0.12 \\
\hline
\end{tabular}

Table 5 shows that there were as many as 238 trees in the study area with a total biomass of 16.12 ton $\mathrm{ha}^{-1}$ so that a carbon stock is obtained of 7.58 ton $\mathrm{ha}^{-1}$. The high carbon stock before logging in this study was due to the high DBH of trees. DBH affects the high value of biomass. The greater the $\mathrm{DBH} \mathrm{CO}$ indicates more amount of $\mathrm{CO}_{2}$ being absorbed. Previous studies (Ilyas 2011; Seto et al. 2014) revealed a close relationship between dry biomass and tree diameter variables. This is because the tree diameter grows through continuous cell division and gets slower at a certain age. This growth occurs in the radial direction of the cambium. Eventually, new cells will be formed which will increase the diameter of the stem.

Table 5 also shows that the 238 trees in the study area can absorb 28.37 ton $\mathrm{CO}_{2}$ eq of carbon. The high carbon uptake illustrates the ability of the stands in the study area to fix $\mathrm{CO}_{2}$ which is then stored in the form of carbon stocks in tree stands. Setyowati et al. (2014) stated that the ability of plants to absorb carbon dioxide varies. Many factors affect the absorption of carbon dioxide, which is determined by the amount of magnesium that will give the leaves a dark green color. Hardjana and Fajri (2011) showed the contribution of $\mathrm{CO}_{2}$ absorption from the atmosphere by Shorea leprosula plants in the IUPHHK-HA area of PT. ITCIKU ranged from $0.54-10.17$ ton $\mathrm{ha}^{-1} \mathrm{CO}_{2}$, with an annual average ability to absorb $\mathrm{CO}_{2}$ gas from the atmosphere of 0.27-1.69 ton $\mathrm{ha}^{-1}$ year. Iticha (2017) showed that biomass accumulation was comparatively larger in natural forests than in plantation forests due to maturity, intactness, and species diversity. The total C storage capacity of the forest ranged from $107.12 \mathrm{Mg} \mathrm{ha}^{-1}$ for acacia plantation to $453.21 \mathrm{Mg} \mathrm{ha} \mathrm{g}^{-1}$ for the intact natural forest. Yunita (2016) showed that the increase in carbon stocks is due to the increasing age of the meranti stands. Meranti forests aged 6, 8, and 10 years are thought to be able to absorb $\mathrm{CO}_{2}$ gas as much as 28.01 ton $\mathrm{ha}^{-1}, 172.83$ ton $\mathrm{ha}^{-1}$, and 274.86 ton ha ${ }^{-1}$. Masripatin et al. (2010) stated that the carbon stock in various land cover classes in the natural forest ranged from 7.50-264.70 t.C.ha-1 .

Carbon stock in plantation forests showed by several studies. Ratnaningsih et al. (2014) showed that natural forest has a carbon stock potential of 76,651 ton $\mathrm{ha}^{-1}$, shrub ecosystem of 0.973 ton $\mathrm{ha}^{-1}$, and Eucalyptus pellita plantations of 33,706 to 70,930 tons ha ${ }^{-1}$, depend on its age. Chairul et al. (2016) showed that the carbon content of plant life at the top of the primary forests was $1,359,884.68 \mathrm{~kg} \mathrm{ha}^{-1}$, logged forest $610,429.67 \mathrm{~kg} \mathrm{ha}^{-1}$, and timber mix 360,793.70 $\mathrm{kg} \mathrm{ha} \mathrm{ha}^{-1}$. Rahmayanti et al. (2019) showed that the amount of carbon stocks in the biomass 2,808,363.28 ton $\mathrm{C} \mathrm{ha}^{-1}$, necromass 2004,437 ton $\mathrm{C} \mathrm{ha}^{-1}$ and $560.938,5$ ton $\mathrm{C} \mathrm{ha}^{-1}$ in peatland. The results of several studies on carbon stocks in natural and plantation forests show that carbon stocks in natural forests are higher than in plantation forests. This is due to the high potential for stands in natural 
forests, especially the volume of wood in the form of diameter at breast height and tree height. The potential for carbon sequestration of a tree in natural forests is higher than in plantation forests.

\subsection{Biomass and Carbon After Felling}

Trees felling could affect the potential of carbon stock and $\mathrm{CO}_{2}$ absorption. The biomass potential and carbon stock after felling are presented in Table 6. The results showed that there were as many as 30 trees felled, resulting in a reduction in the amount of biomass of 16.12 ton $\mathrm{ha}^{-1}$ to 5.15 ton $\mathrm{ha}^{-1}$ or a decrease of $68.05 \%$ (the amount of biomass before felling was 16.12 ton $\mathrm{ha}^{-1}$ minus the amount of biomass lost during felling namely 10.97 ton $^{\mathrm{ha}^{-1}}$ ) (Table 6-8). The reduction in biomass resulted in a decrease in the after-felling carbon stock of 2.42 ton ha ${ }^{-1}$ $(68.07 \%)$. The reduction in carbon stock during logging in this study could decrease $\mathrm{CO}_{2}$ absorption or an increase in $\mathrm{CO}_{2}$ emissions calculated at the $\mathrm{CO}_{2}$ equivalent (ton $\mathrm{CO}_{2}$ eq ha ${ }^{-1}$ ) of 18.93 ton $\mathrm{CO}_{2}$ eq ha ${ }^{-1}(81.00 \%) . \mathrm{CO}_{2}$ uptake by stands describes the stand's ability to fix $\mathrm{CO}_{2}$ which is then stored in the form of carbon stocks in the tree stands.

Table 6. Biomass and carbon stock potential during felling

\begin{tabular}{lccccc}
\hline Biomass (kg) & $\begin{array}{c}\text { Biomass } \\
\left(\mathbf{k g ~ h a}^{-\mathbf{1}}\right)\end{array}$ & $\begin{array}{c}\text { Biomass } \\
\left.\text { (ton ha }^{-1}\right)\end{array}$ & $\begin{array}{c}\text { C stock } \\
\left(\text { ton ha }^{-\mathbf{1}}\right)\end{array}$ & $\begin{array}{c}\mathbf{C O}_{2} \text { equivalent } \\
\left(\text { tonCO }_{\mathbf{2}} \mathbf{e q}\right)\end{array}$ \\
\hline Total & $65,836.30$ & $10,972.72$ & 10.97 & 5.16 & 18.93 \\
Average & $2,194.54$ & 365.76 & 0.37 & 0.17 & 0.63 \\
\hline
\end{tabular}

Table 7. Biomass and carbon stock potential after felling

\begin{tabular}{lccccc}
\hline Biomass (kg) & $\begin{array}{c}\text { Biomass } \\
\left(\mathbf{k g ~ h a}^{-1}\right)\end{array}$ & $\begin{array}{c}\text { Biomass } \\
\left(\text { (ton ha }^{-1}\right)\end{array}$ & $\begin{array}{c}\text { C stock } \\
\left(\text { ton ha }^{-1}\right)\end{array}$ & $\begin{array}{c}\mathbf{C O}_{2} \text { equivalent } \\
\left.\text { (tonCO }_{\mathbf{2}} \mathbf{e q}\right)\end{array}$ \\
\hline Total & $30,866.12$ & $5,144.35$ & 5.15 & 2.42 & 4.44 \\
Average & 148.39 & 2.47 & 0.02 & 0.01 & 0.02 \\
\hline
\end{tabular}

Table 8. Percentage reduction in carbon sequestration potential

\begin{tabular}{|c|c|c|c|c|}
\hline Observation & $\begin{array}{l}\text { Before } \\
\text { felling }\end{array}$ & During felling & After felling & $\%$ Decrease \\
\hline Amount of tree & 238 & 30 & 208 & 12.61 \\
\hline Research area (ha) & 6 & 6 & 6 & 0.00 \\
\hline Amount of biomass $(\mathrm{kg})$ & $96,702.42$ & $65,836.30$ & $30,866.12$ & 68.08 \\
\hline Amount of biomass $\left(\mathrm{kg} \mathrm{ha}^{-1}\right)$ & $16,117.07$ & $10,972.72$ & $5,144.35$ & 68.08 \\
\hline Amount of biomass (ton $\mathrm{ha}^{-1}$ ) & 16.12 & 10.97 & 5.15 & 68.05 \\
\hline Carbon stock (ton ha ${ }^{-1}$ ) & 7.58 & 5.16 & 2.42 & 68.07 \\
\hline $\mathrm{CO}_{2}$ equivalent (tonCO $\mathrm{eq}_{2} \mathrm{ha}^{-1}$ ) & 28.37 & 18.93 & 4.44 & 81.00 \\
\hline
\end{tabular}

Felling activities have consequences for the loss of biomass so that the ability to absorb $\mathrm{CO}_{2}$ is reduced. The $\mathrm{CO}_{2}$ used by plants in the photosynthetic process will be stored in the form of biomass. If the $\mathrm{CO}_{2}$ absorption volume is reduced, there will certainly be an additional accumulation of $\mathrm{CO}_{2}$ in the atmosphere. Hardjana and Fajri (2011) stated that tree releases carbon into the atmosphere when it is felled. Pukkala (2017) stated that felling had a negative effect on carbon balance for about three decades compared to a no-cutting alternative. Because the net effect of cuttings is negative in the short term, a short-sighted analysis always leads to a no-cutting 
decision when the aim is to maximize carbon sequestration. However, this is a wrong decision in the longer term.

Several research results have studied the reduced carbon stocks and carbon emissions due to timber harvesting. Junaedi (2014) showed that timber harvesting with the TPTI silvicultural system caused carbon loss of 80.94 ton $\mathrm{CO}_{2} /$ ha/year and $\mathrm{CO}_{2}$ emissions released into the atmosphere of 297.02 ton $\mathrm{CO}_{2} \mathrm{~h}^{-1}$ /year. Wayan (2011) reported the average potential carbon storage of 114.14 ton $\mathrm{C} \mathrm{ha}^{-1}$. After the timber harvesting activity was carried out, the potential carbon emission was 34.53 tons $\mathrm{C} \mathrm{ha}^{-1}$, or a reduction in carbon storage of $30.25 \%$. This potential carbon emission derived from carbon due to harvesting trees of 27.64 ton $\mathrm{C} \mathrm{ha}^{-1}$ and carbon loss due to tree damage caused by timber harvesting is 6.89 ton $\mathrm{C} \mathrm{ha}^{-1}$. Firma and Rusolono (2012) stated that timber harvesting activities were potentially releasing carbon into the air from tree stands that are heavily damaged with an average of 46,74 ton $\mathrm{C} \mathrm{ha}^{-1}$ or $38,90 \%$ of potential carbon stocks prior to harvesting timber.

The reduction in carbon absorption due to timber harvesting could be minimized if the application of reduced impact logging (RIL) in the field is implemented correctly and appropriately. In addition, the application of RIL could reduce the amount of felled waste produced to minimize $\mathrm{CO}_{2}$ emissions. Ceruttia et al. (2017) stated that FMPs showed substantial opportunity to reduce carbon emissions from forests while presenting logging companies with acceptable financial trade-offs. Sustainable production of natural forest management can reduce carbon loss by 90,521 ton $\mathrm{C}_{\text {year }}{ }^{-1}$, reduce $\mathrm{CO}_{2}$ emissions due to tree/stands damage by $39 \% /$ year (Fitri 2013).

\section{Conclusions}

Timber harvesting could contribute a negative effect in reducing carbon stocks by 2.42 ton $\mathrm{ha}^{-1}$ or a $68.07 \%$ decrease in comparison to the condition before felling. A decrease in carbon stock brought consequences in the decreasing ability of these areas to absorb $\mathrm{CO}_{2}$. A decrease in $\mathrm{CO}_{2}$ absorption due to felling in the study area was $81.00 \%$. Therefore, timber harvesting activities must be carried out following the principles of reduced impact logging (RIL) to reduce the occurrence of carbon stock decrease and the decrease in the ability of forests to absorb $\mathrm{CO}_{2}$.

\section{Acknowledgments}

The authors extend their gratitude toward all staff of PT Inhutani I who have helped the field data collection.

\section{References}

Alvarez, E., Duque, A., Saldarriaga, J., Cabrera, K., De Las Salas, G., Del Valle, I., Lema, A., Moreno, F., Orrego, S., and Rodríguez, L. 2012. Tree Above-Ground Biomass Allometries for Carbon Stocks Estimation in the Natural Forests of Colombia. Forest Ecology and Management 267: 297-308. DOI: 10.1016/j.foreco.2011.12.013

Cardenas, E., Orellana, L. H., Konstantinidis, K. T., and Mohn, W. M. 2018. Effects of Timber Harvesting on the Genetic Potential for Carbon and Nitrogen Cycling in Five North American Forest Ecozones. Scientific Reports 8: 3142. DOI: 10.1038/s41598-018-21197-0 
Ceruttia, P. O., Suryadarmab, D., Nasib, R., Fornic, R., Medjibed, V., Delione, S., and Bastin, D. 2017. The Impact of Forest Management Plans on Trees and Carbon: Modeling a Decade of Harvesting Data. Journal of Forest Economic 27: 1-9. DOI: 10.1016/j.jfe.2017.01.004

Chairul, Muchktar, E., Mansyurdin, Tesri, M., and Indra G. 2016. The Structure of Vegetation Density and the Estimation of Carbon Content in Some Conditions of Forest in Siberut Island, West Sumatera. Jurnal Metamorfosa 3(1): 15-22. DOI: 10.24843/metamorfosa.2016.v03.i01.p03

Chave, J., Andalo, C., Brown, S., Cairns, M. A., Chambers, J. Q., Eamus, D., Folster, H., Fromard, F., Higuchi, N., Kira, T., Lescure, J. P., Nelson, B. W., Ogawa, H., Puig, H. and Yamakur, A. T. 2005. Tree Allometry and Improved Estimation of Carbon Stocks and Balance in Tropical Forests. Oecologia 145: 87-99. DOI: 10.1007/s00442-005-0100-x

Firma, and Rusolono, T. 2012. Emisi Karbon Potensial Akibat Pemanenan Kayu Secara Mekanis di Hutan Alam Tropis (Kasus Konsesi Hutan PT. Salaki Summa Sejahtera, Pulau Siberut, Provinsi Sumatera Barat). Skripsi. Institut Pertanian Bogor. Indonesia.

Fitri, R. M. N. 2013. Reduksi Emisi Karbon Melalui Pengelolaan Hutan Alam Produksi Lestari. Jurnal Hutan Tropis 1(1): 76-84. DOI: 10.20527/jht.v1i1.1487

Garcia, F. R., Fredericksen, T. S., Lozada, S. V., and Agramont, A. R. E. 2019. Impact of Timber Harvesting on Carbon Storage in Montane Forests of Central Mexico. New Forests 50(6): 1043-1061. DOI: 10.1007/s11056-019-09714-Z

Gavali, R. S., and Shaikh, H. M. Y. 2016. Estimation of Carbon Storage in the Tree Growth of Solapur University Campus, Maharashtra, India. International Journal of Science and Research 5(4): 2364-2367. DOI: 10.21275/v5i4.nov163155

Hairiah, K., Ekadinata, A., Sari, R. R., and Rahayu, S. 2011. Pengukuran Cadangan Karbon: Dari Tingkat Lahan ke Bentang Lahan. Petunjuk Praktis. Edisi Kedua. World Agroforestry Centre, ICRAF SEA Regional Office, University of Brawijaya, Malang, Indonesia.

Hardjana, A. K., and Fajri, M. 2011. Kemampuan Tanaman Meranti (Shorea Leprosula) dalam Menyerap Emisi Karbon $\left(\mathrm{CO}_{2}\right)$ di Kawasan Hutan IUPHHK-HA PT ITCIKU Kalimantan Timur. Jurnal Penelitian Dipterokarpa 5(1): 39-46. DOI: 10.20886/jped.2011.5.1.39-46

Heinonen, T., Pukkala, T., Mehtätalo, L., Asikaine, A., Kangas, J., and Peltola, H. 2017. Scenario Analyses for the Effects of Harvesting Intensity on Development of Forest Resources, Timber Supply, Carbon Balance, and Biodiversity of Finnish Forestry. Forest Policy and Economics 80: 80-98. DOI: 10.1016/j.forpol.2017.03.011

Höglmeier, K., Weber-Blaschke, G., and Richter, K. 2015. Potentials for Cascading of Recovered Wood from Building Deconstruction - A Case Study for South-East Germany. Resources, Conservation and Recycling 78: 81-91. DOI: 10.1016/j.resconrec.2013.07.004

Ilyas, S. 2011. Pendugaan Biomassa pada Tegakan Hasil Revegetasi Lahan Bekas Tambang Batubara Studi Kasus Tanaman Johar (Cassia siamea, Lamk.) di PT. Multi Sarana Avindo, Kalimantan Timur. Mulawarman Scientifie 10(1): 29-38.

IPCC. 2006. 2006 IPCC Guidelines for National Greenhouse Gas Inventories. Eggleston H.S., Buendia L., Miwa K., Ngara T. and Tanabe K. (eds). Institute for Global Environmental Strategies (IGES), Japan.

Istomo, and Farida, N. Y. 2017. Potensi Simpanan Karbon di Atas Permukaan Tanah Tegakan Acacia nilotica 1. (willd) ex. Del. di Taman Nasional Baluran, Jawa Timur. Jurnal Pengelolaan Sumberdaya Alam dan Lingkungan 7(2): 155-162. DOI: 10.29244/jpsl.7.2.155162 
Iticha, B. 2017. Ecosystem Carbon Storage and Partitioning in Chato Afromontane Forest: Its Climate Change Mitigation and Economic Potential. International Journal of Environment, Agriculture and Biotechnology 2(4): 1785-1794. DOI: 10.22161/ijeab/2.4.41

Junaedi, A. 2014. Estimasi Jumlah Karbon Vegetasi yang Hilang Akibat Kegiatan Pemanenan Kayu di Hutan Alam Tropis. Jurnal Hutan Tropis 2(2): 146-151. DOI: 10.20527/jht.v2i2.1576

Kasianus, R., Astianti, D., and Iskandar. 2018. Estimasi Kandungan Karbon Tegakan Hutan di Atas Permukaan Tanah pada Berbagai Kelas Tutupan Tajuk di Hutan Adat Pengajit Kabupaten Bengkayang. Jurnal Hutan Lestari 6(4): 952-962. DOI: 10.26418/jhl.v6i4.30123 Kusmana, C. 2017. Metode Survey dan Interpretasi Data Vegetasi. IPB Press. Bogor, Indonesia. Lukito, M., and Rohmatiah, A. 2013. Estimasi Biomassa dan Karbon Tanaman Jati Umur 5 Tahun. AGRI-TEK 14(1): 1-23.

Maryadi, A., Rafdinal, and Linda, R. 2019. Kajian Biomasa Tegakan Atas Permukaan (Aboveground Biomass) dan Cadangan Karbon di Beberapa Taman Kota Pontianak. Protobiont 8(3): 73-80. DOI: 10.26418/protobiont.v8i3.36855

Masripatin, N., Ginoga, K., Pari, G., Darmawan, W. Y., Siregar, C. A., Wibowo, A., Puspasari, D., Utomo, A. S., Sakuntaladewi, N., Lugina, M., Indartik, Wulandari, W. S., Darmawan, S., Heryansah, I., Heriyanto, Seringoringo, H., Damayanti, R., Anggraeni, D., Krisnawati, H., Maryani, R., Apriyanto, D., and Subekti, B. 2010. Cadangan Karbon pada Berbagai Tipe Hutan dan Jenis Tanaman di Indonesia. Pusat Penelitian dan Pengembangan Perubahan Iklim dan Kebijakan. Bogor, Indonesia.

Poudyal, B .H., Maraseni, T. N., and Cockfield, G. 2019. Implications of Selective Harvesting of Natural Forests for Forest Product Recovery and Forest Carbon Emissions: Cases from Tarai Nepal and Queensland Australia. Forests 10: 693. DOI: 10.3390/f10080693

Pukkala, T. 2018. Carbon Forestry is Surprising. Forest Ecosystems 5(11): 1-11. DOI: 10.1186/s40663-018-0131-5

Pukkala, T. 2017. Does Management Improve the Carbon Balance of Forestry?. Forestry 90(1): 125-135. DOI: 10.1093/forestry/cpw043

Rahmayanti, F. D., Joy, B., and Husodo, T. 2019. Kajian Potensi Cadangan Karbon (Carbon Stock) Hutan Tanaman Acacia crassicarpa pada Lahan Gambut (Studi Kasus di Hutan Tanaman Industri Kabupaten Bengkalis, Provinsi Riau). Jurnal Agrowiralodra 2(1): 1-8. DOI: 10.31943/agrowiralodra.v2i1.25

Ratnaningsih, A. T., Suwarno, E., and Insusanty, E. 2014. Potential of Carbon for Some Type of Vegetation in the Forest Plantation. Jurnal Ilmiah Pertanian 11(2): 43-55. DOI: 10.31849/jip.v11i2.1248

Russell, A. E., and Kumar, B. M. 2017. Forestry for a Low-Carbon Future: Integrating Forests and Wood Products into Climate Change Strategies. Environment: Science and Policy for Sustainable Development 59(2): 16-23. DOI: 10.1080/00139157.2017.1274580

Seto, K. C., Dhakal, S., Bigio, A., Blanco, H., Delgado, G. C., and Dewar, D. 2014. Human Settlements, Infrastructure and Spatial Planning. Intergovernmental Panel on Climate Change. Working Group III- Mitigation of Climate Change. Cambridge University Press. Cambridge, New York.

Setyowati, Liesnoor, D., and Nana, K. T. M. 2014. Ruang Terbuka Hijau Potensi Ruang Terbuka Hijau Dalam Meredam Cemaran Udara. CV Sanggar Krida Adhitama. Semarang, Indonesia. 
Sist, P., Sheil, D., Kartawinata, K., and Priyadi, H. 2003. Reduced-Impact Logging in Indonesian Borneo: Some Results Confirming the Need For New Silvicultural Prescriptions. Forest Ecology and Management 179(1-3): 415-427. DOI: 10.1016/S0378-1127(02)00533-9

Superales, J. B. 2016. Carbon Dioxide Capture and Storage Potential of Mahogany (Swietenia macrophylla) Saplings. International Journal of Environmental Science and Development 7(8): 611-614. DOI: 10.18178/ijesd.2016.7.8.849

Wayana, P. A. 2011. Pendugaan Emisi Karbon Potensial Akibat Pemanenan Kayu Secara Mekanis Pada Hutan Alam Tropis (Studi Kasus di IUPHHK PT. Sarmiento Parakantja Timber, Kalimantan Tengah). Skripsi. Institut Pertanian Bogor. Bogor, Indonesia.

Ximenes, F., Bi, H., Cameron, N., Coburn, R., Maclean, M., Matthew, D. S, Roxburgh, S., Ryan, M., Williams, J., and Ken, B. 2016. Carbon Stocks and Flows in Native Forests and Harvested Wood Products in SE Australia. Forest and Wood Products Australia Limited. Melbourne, Australia.

Yunita, L. 2016. Pendugaan Cadangan Karbon Tegakan Meranti (Shorea leprosula) di Hutan Alam pada Area SILIN PT Inhutani II Pulau Laut Kalimantan Selatan. Jurnal Hutan Tropis 4(2): 187-197. DOI: 10.20527/jht.v4i2.3606 